\title{
Davis Pond Freshwater Diversion Biomonitoring: Prediversion and Postdiversion Freshwater Fish Data
}

Data Series 604

Revised 2012 
Cover. Swamp area in the Davis Pond, La., study site. 


\section{Davis Pond Freshwater Diversion Biomonitoring: Prediversion and Postdiversion Freshwater Fish Data}

By Jill A. Jenkins, Heather M. Olivier, Rassa 0. Draugelis-Dale, and Michael D. Kaller

Data Series 604

Revised 2012 


\section{U.S. Department of the Interior \\ KEN SALAZAR, Secretary \\ U.S. Geological Survey \\ Marcia K. McNutt, Director}

U.S. Geological Survey, Reston, Virginia: 2011

Revised: 2012

This and other USGS information products are available at http://store.usgs.gov/

U.S. Geological Survey

Box 25286, Denver Federal Center

Denver, CO 80225

To learn about the USGS and its information products visit http://www.usgs.gov/ 1-888-ASK-USGS

Any use of trade, product, or firm names is for descriptive purposes only and does not imply endorsement by the U.S. Government.

Although this report is in the public domain, permission must be secured from the individual copyright owners to reproduce any copyrighted materials contained within this report.

Suggested citation:

Jenkins, J.A., Olivier, H.M., Draugelis-Dale, R.O., and Kaller, M.D., 2011, Davis Pond freshwater diversion biomonitoring — prediversion and postdiversion freshwater fish data: U.S. Geological Survey Data Series 604. Revised 2012. 


\section{Contents}

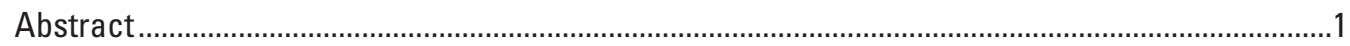

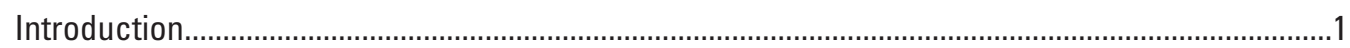

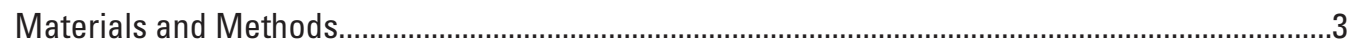

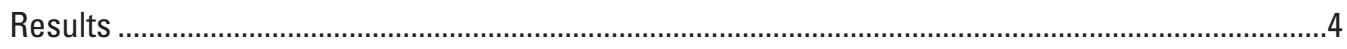

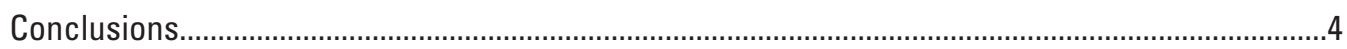

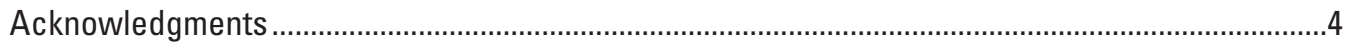

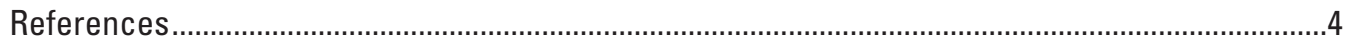

\section{Figures}

1. Sampling sites for fish from the Mississippi River in relation to

freshwater diversion structures in the area.

2. Annual mean water flow discharge at the Davis Pond freshwater diversion structure near Boutte, La. Data are from U.S. Geological

Survey surface-water daily statistics.

3-27 Access figures from index page.

3. Fish weights in grams for the Davis Pond freshwater postdiversion sampling.

4. A, Total organochlorines from largemouth bass, blue catfish, and striped mullet collected from Davis Pond postdiversion sites from December 2007 through February 2009. $B$, Three-dimensional comparison of Davis Pond prediversion and postdiversion values for organochlorines by wet weight. $C$, Organochlorine wet weight concentrations from fish collected from sites in southeastern Louisiana during the Davis Pond postdiversion study (2007-9).

5. A, Total polychlorinated biphenyls from largemouth bass, blue catfish, and striped mullet collected from Davis Pond postdiversion sites from December 2007 through February 2009. B, Three-dimensional comparison of Davis Pond prediversion and postdiversion values for polychlorinated biphenyls by wet weight. $C$, Polychlorinated biphenyl wet weight concentrations from fish collected from sites in southeastern Louisiana during the Davis Pond postdiversion study (2007-9).

6. A, Total DDT derivatives from largemouth bass, blue catfish, and striped mullet collected from Davis Pond postdiversion sites from December 2007 through February 2009. $B$, Three-dimensional comparison of Davis Pond prediversion and postdiversion values for DDT by wet weight. $C$, Proportion of different DDT isomers collected from Davis Pond postdiversion sites from December 2007 through February 2009.

7. A, Total polycyclic aromatic hydrocarbons from largemouth bass, blue catfish, and striped mullet collected from Davis Pond postdiversion sites from December 2007 through February 2009. B, Three-dimensional comparison of Davis Pond prediversion and postdiversion values for polycyclic aromatic hydrocarbons by wet weight. $C$, Polycyclic aromatic hydrocarbon wet weight concentrations from fish collected from sites in southeastern Louisiana during the Davis Pond postdiversion study (2007-9). 
8. A, Total aliphatic hydrocarbons from largemouth bass, blue catfish, and striped mullet collected from Davis Pond postdiversion sites from December 2007 through February 2009. B, Three-dimensional comparison of Davis Pond prediversion and postdiversion values for aliphatic hydrocarbons by wet weight. C, Aliphatic hydrocarbon wet weight concentrations from fish collected from sites in southeastern Louisiana during the Davis Pond postdiversion study (2007-9).

9. A, Aluminum in dry weight from largemouth bass, blue catfish, and striped mullet collected from Davis Pond postdiversion sites from December 2007 through February 2009. B, Three-dimensional comparison of Davis Pond prediversion and postdiversion values for aluminum by dry weight. $C$, Aluminum dry and wet weight concentrations from fish collected from sites in southeastern Louisiana during the Davis Pond postdiversion study (2007-9).

10. A, Arsenic in dry weight from largemouth bass, blue catfish, and striped mullet collected from Davis Pond postdiversion sites from December 2007 through February 2009. B, Three-dimensional comparison of Davis Pond prediversion and postdiversion values for arsenic by dry weight. $C$, Arsenic dry and wet weight concentrations from fish collected from sites in southeastern Louisiana during the Davis Pond postdiversion study (2007-9).

11. A, Barium in dry weight from largemouth bass, blue catfish, and striped mullet collected from Davis Pond postdiversion sites from December 2007 through February 2009. B, Three-dimensional comparison of Davis Pond prediversion and postdiversion values for barium by dry weight. $C$, Barium dry and wet weight concentrations from fish collected from sites in southeastern Louisiana during the Davis Pond postdiversion study (2007-9).

12. $A$, Boron in dry weight from largemouth bass, blue catfish, and striped mullet collected from Davis Pond postdiversion sites from December 2007 through February 2009. $B$, Three-dimensional comparison of Davis Pond prediversion and postdiversion values for boron by dry weight. $C$, Boron dry and wet weight concentrations from fish collected from sites in southeastern Louisiana during the Davis Pond postdiversion study (2007-9).

13. $A$, Cadmium in dry weight from largemouth bass, blue catfish, and striped mullet collected from Davis Pond postdiversion sites from December 2007 through February 2009. $B$, Three-dimensional comparison of Davis Pond prediversion and postdiversion values for cadmium by dry weight. $C$, Cadmium dry and wet weight concentrations from fish collected from sites in southeastern Louisiana during the Davis Pond postdiversion study (2007-9).

14. $A$, Chromium in dry weight from largemouth bass, blue catfish, and striped mullet collected from Davis Pond postdiversion sites from December 2007 through February 2009. B, Three-dimensional comparison of Davis Pond prediversion and postdiversion values for chromium by dry weight. $C$, Chromium dry and wet weight concentrations from fish collected from sites in southeastern Louisiana during the Davis Pond postdiversion study (2007-9).

15. A, Copper in dry weight from largemouth bass, blue catfish, and striped mullet collected from Davis Pond postdiversion sites from December 2007 through February 2009. $B$, Three-dimensional comparison of Davis Pond prediversion and postdiversion values for copper by dry weight. $C$, Copper dry and wet weight concentrations from fish collected from sites in southeastern Louisiana during the Davis Pond postdiversion study (2007-9). 
16. A, Iron in dry weight from largemouth bass, blue catfish, and striped mullet collected from Davis Pond postdiversion sites from December 2007 through February 2009. B, Three-dimensional comparison of Davis Pond prediversion and postdiversion values for iron by dry weight. $C$, Iron dry and wet weight concentrations from fish collected from sites in southeastern Louisiana during the Davis Pond postdiversion study (2007-9).

17. A, Lead in dry weight from largemouth bass, blue catfish, and striped mullet collected from Davis Pond postdiversion sites from December 2007 through February 2009. $B$, Three-dimensional comparison of Davis Pond prediversion and postdiversion values for lead by dry weight. $C$, Lead dry and wet weight concentrations from fish collected from sites in southeastern Louisiana during the Davis Pond postdiversion study (2007-9).

18. $A$, Magnesium in dry weight from largemouth bass, blue catfish, and striped mullet collected from Davis Pond postdiversion sites from December 2007 through February 2009. B, Three-dimensional comparison of Davis Pond prediversion and postdiversion values for magnesium by dry weight. $C$, Magnesium dry and wet weight concentrations from fish collected from sites in southeastern Louisiana during the Davis Pond postdiversion study (2007-9).

19. $A$, Manganese in dry weight from largemouth bass, blue catfish, and striped mullet collected from Davis Pond postdiversion sites from December 2007 through February 2009. B, Three-dimensional comparison of Davis Pond prediversion and postdiversion values for manganese by dry weight. $C$, Manganese dry and wet weight concentrations from fish collected from sites in southeastern Louisiana during the Davis Pond postdiversion study (2007-9).

20. $A$, Mercury in dry weight from largemouth bass, blue catfish, and striped mullet collected from Davis Pond postdiversion sites from December 2007 through February 2009. $B$, Three-dimensional comparison of Davis Pond prediversion and postdiversion values for mercury by dry weight. $C$, Mercury dry and wet weight concentrations from fish collected from sites in southeastern Louisiana during the Davis Pond postdiversion study (2007-9).

21. Total methylmercury in dry weight from largemouth bass collected from Davis Pond postdiversion sites from December 2007 through February 2009.

22. $A$, Nickel in dry weight from largemouth bass, blue catfish, and striped mullet collected from Davis Pond postdiversion sites from December 2007 through February 2009. B, Three-dimensional comparison of Davis Pond prediversion and postdiversion values for nickel by dry weight. $C$, Nickel dry and wet weight concentrations from fish collected from sites in southeastern Louisiana during the Davis Pond postdiversion study (2007-9).

23. $A$, Selenium in dry weight from largemouth bass, blue catfish, and striped mullet collected from Davis Pond postdiversion sites from December 2007 through February 2009. $B$, Three-dimensional comparison of Davis Pond prediversion and postdiversion values for selenium by dry weight. $C$, Selenium dry and wet weight concentrations from fish collected from sites in southeastern Louisiana during the Davis Pond postdiversion study (2007-9).

24. A, Sulfur in dry weight from largemouth bass, blue catfish, and striped mullet collected from Davis Pond postdiversion sites from December 2007 through February 2009. $B$, Sulfur dry and wet weight concentrations from fish collected from sites in southeastern Louisiana during the Davis Pond postdiversion study (2007-9). 
25. A, Strontium in dry weight from largemouth bass, blue catfish, and striped mullet collected from Davis Pond postdiversion sites from December 2007 through February 2009. $B$, Three-dimensional comparison of Davis Pond prediversion and postdiversion values for strontium by dry weight. $C$, Strontium dry and wet weight concentrations from fish collected from sites in southeastern Louisiana during the Davis Pond postdiversion study (2007-9).

26. A, Vanadium in dry weight from largemouth bass, blue catfish, and striped mullet collected from Davis Pond postdiversion sites from December 2007 through February 2009. B, Three-dimensional comparison of Davis Pond prediversion and postdiversion values for vanadium by dry weight. $C$, Vanadium dry and wet weight concentrations from fish collected from sites in southeastern Louisiana during the Davis Pond postdiversion study (2007-9).

27. A, Zinc in dry weight from largemouth bass, blue catfish, and striped mullet collected from Davis Pond postdiversion sites from December 2007 through February 2009. $B$, Three-dimensional comparison of Davis Pond prediversion and postdiversion values for zinc by dry weight. $C$, Zinc dry and wet weight concentrations from fish collected from sites in southeastern Louisiana during the Davis Pond postdiversion study (2007-9).

\section{Tables}

1-11 Access tables from index page.

1. List of specific analytes investigated in the Davis Pond freshwater prediversion and postdiversion samplings.

2. Chemical names and alternatives, abbreviations, and Chemical Abstracts Service registry numbers.

3. Fish health and age data and collection dates of fish for the Davis Pond postdiversion sampling.

4. Organochlorines detected in fish collected from Davis Pond postdiversion sites from December 2007 to February 2009.

5. Polycyclic aromatic hydrocarbons detected in fish collected from Davis Pond postdiversion sites from December 2007 to February 2009.

6. Aliphatic hydrocarbons detected in fish collected from Davis Pond postdiversion sites from December 2007 to February 2009.

7. Statistically significant analysis of variance probability results of levels of total organic contaminants from fish whole bodies at the Mississippi River and all marsh sites (two-site analysis) for Davis Pond postdiversion sampling (2007-9).

8. Statistically significant analysis of variance probability results of total organic contaminants from fish whole bodies at the Mississippi River and all marsh sites (four-site analysis) for Davis Pond postdiversion sampling (2007-9).

9. Statistically significant analysis of variance probability results of levels of inorganic contaminants from fish whole bodies at the Mississippi River and all marsh sites (two-site analysis) for Davis Pond postdiversion sampling (2007-9).

10. Statistically significant analysis of variance probability results of levels of inorganic contaminants from fish whole bodies at the Mississippi River and all marsh sites (four-site analysis) for Davis Pond postdiversion sampling (2007-9).

11. Trace element ranges detected in fish from the prediversion and postdiversion studies at Caernarvon (1990-94) and Davis Pond (2001, 2007-9) in Louisiana. 


\section{Appendix}

1-2 Access appendixes from index page.

1. Analytical Methods Performed at TDI Brooks International, Inc. (TDI), Laboratory for Triazines in Water and Organic and Inorganic Compounds in Fish Tissues

2. Statistical Transformations Applied to Tables 7-10

\section{Conversion Factors}

\begin{tabular}{|c|c|c|}
\hline Multiply & By & To obtain \\
\hline \multicolumn{3}{|c|}{ Length } \\
\hline centimeter $(\mathrm{cm})$ & 0.3937 & inch (in.) \\
\hline millimeter (mm) & 0.03937 & inch (in.) \\
\hline meter $(\mathrm{m})$ & 3.281 & foot $(\mathrm{ft})$ \\
\hline kilometer $(\mathrm{km})$ & 0.6214 & mile (mi) \\
\hline \multicolumn{3}{|c|}{ Volume } \\
\hline liter (L) & 33.82 & ounce, fluid (fl. oz) \\
\hline liter (L) & 61.02 & cubic inch $\left(\right.$ in $\left.^{3}\right)$ \\
\hline \multicolumn{3}{|c|}{ Flow rate } \\
\hline cubic meter per second $\left(\mathrm{m}^{3} / \mathrm{s}\right)$ & 35.31 & cubic foot per second $\left(\mathrm{ft}^{3} / \mathrm{s}\right)$ \\
\hline \multicolumn{3}{|c|}{ Mass } \\
\hline $\operatorname{gram}(\mathrm{g})$ & 0.03527 & ounce, avoirdupois (oz) \\
\hline kilogram $(\mathrm{kg})$ & 2.205 & pound avoirdupois (lb) \\
\hline
\end{tabular}

Temperature in degrees Celsius $\left({ }^{\circ} \mathrm{C}\right)$ may be converted to degrees Fahrenheit $\left({ }^{\circ} \mathrm{F}\right)$ as follows:

$$
{ }^{\circ} \mathrm{F}=\left(1.8 x^{\circ} \mathrm{C}\right)+32
$$

Specific conductance is given in microsiemens per centimeter at 25 degrees Celsius $\left(\mu \mathrm{S} / \mathrm{cm}\right.$ at $\left.25^{\circ} \mathrm{C}\right)$. 
Vill 


\title{
Davis Pond Freshwater Diversion Biomonitoring: Prediversion and Postdiversion Freshwater Fish Data
}

\author{
By Jill A. Jenkins, ${ }^{1}$ Heather M. Olivier, ${ }^{2}$ Rassa 0. Draugelis-Dale, ${ }^{1}$ and Michael D. Kaller ${ }^{3}$
}

\begin{abstract}
The diversion of freshwater from the Mississippi River is intended to mitigate saltwater intrusion from the Gulf of Mexico and to lessen the concomitant loss of wetland areas. Though effective, freshwater diversion can affect wildlife and habitat; therefore, prediversion and postdiversion data collections are necessary to identify effects. The Davis Pond freshwater diversion area is located between the Mississippi River and Bayou Lafourche and extends to Barataria Bay Basin, Louisiana. Results and interpretations from the prediversion biomonitoring done in 2001 — which included data on fish, eagles, and bivalves - are presented in the U.S. Geological Survey (USGS) Scientific Investigations Report 2008-5067, "Davis Pond Freshwater Prediversion Biomonitoring Study: Freshwater Fisheries and Eagles." The postdiversion data generated approximately 6 years later from the sampling of fish whole bodies are presented here in this USGS Data Series. An accompanying log of postdiversion study site photographs was also produced in USGS Data Series 605, "Photographic Images Captured While Sampling for Bald Eagles near the Davis Pond Freshwater Diversion Structure in Barataria Bay, Louisiana (2009-10).”
\end{abstract}

\section{Introduction}

This U.S. Geological Survey (USGS) Data Series presents results of chemistry data obtained from analysis of whole bodies of fish collected near the Davis Pond freshwater diversion structure in Louisiana (fig. 1) after the structure was operating at a rate of more than 4,500 cubic feet per second $\left(\mathrm{ft}^{3} / \mathrm{s}\right)$ ("postdiversion monitoring") (U.S. Geological Survey,

\footnotetext{
${ }^{1}$ U.S. Geological Survey.

${ }^{2}$ IAP World Services, Inc., at the U.S. Geological Survey National Wetlands Research Center.

${ }^{3}$ Louisiana State University, Agricultural Center, School of Renewable Natural Resources.
}

National Water Information System, 2010) (fig. 2). The diversion of freshwater from the Mississippi River is intended to mitigate saltwater intrusion from the Gulf of Mexico and to lessen the concomitant loss of wetland areas. In addition to the freshwater inflow, Barataria Bay Basin would receive nutrients, increased flows of sediments, and waterborne and sediment-bound compounds. The prediversion biomonitoring data from 2001 (Jenkins and others, 2008) served as a baseline for concentrations of selected contaminants in bald eagle (Haliaeetus leucocephalus) nestlings (hereafter referred to as "eaglets"), representative freshwater fish, and bivalves. To that end, a USGS Scientific Investigations Report (SIR) (Jenkins and others, 2008) presents background information, prediversion results, relevant comparisons with local and national studies, and interpretations of results. The purpose of performing both prediversion and postdiversion monitoring was to obtain contaminants data to evaluate potential impacts of the operations of the Davis Pond freshwater diversion structure on fish, bivales, and eagles in the downstream marsh area.

The postdiversion sampling occurred approximately 6 years after the prediversion sampling, and the design for sampling fish was the same between the two biomonitoring time periods, facilitating the presentation of data in close parallel for this report. Supplemental publications will address nonfish species data (from eaglet blood and nutria [Myocastor coypus] livers), as well as triazines in water, collected postdiversion through April 2010. The SIR (Jenkins and others, 2008) also provides data on contaminants in eaglet blood and bivalves.

The reader is referred to the related SIR (Jenkins and others, 2008) for information on the study's conception in the 1990s (U.S. Army Engineer District, 1995), sampling design, interpretations of biological relevance of contaminant levels, and a brief literature review. Specifics of the sampling design are in accordance with the initial U.S. Fish and Wildlife Service (USFWS) 1984 biological opinion written by Dennis Jordan, then field supervisor of the USFWS Endangered Species Field Office, and the 1996 revision for the Davis Pond diversion as mandated by the Endangered Species Act of 1973. The USFWS provides oversight of the Davis Pond 


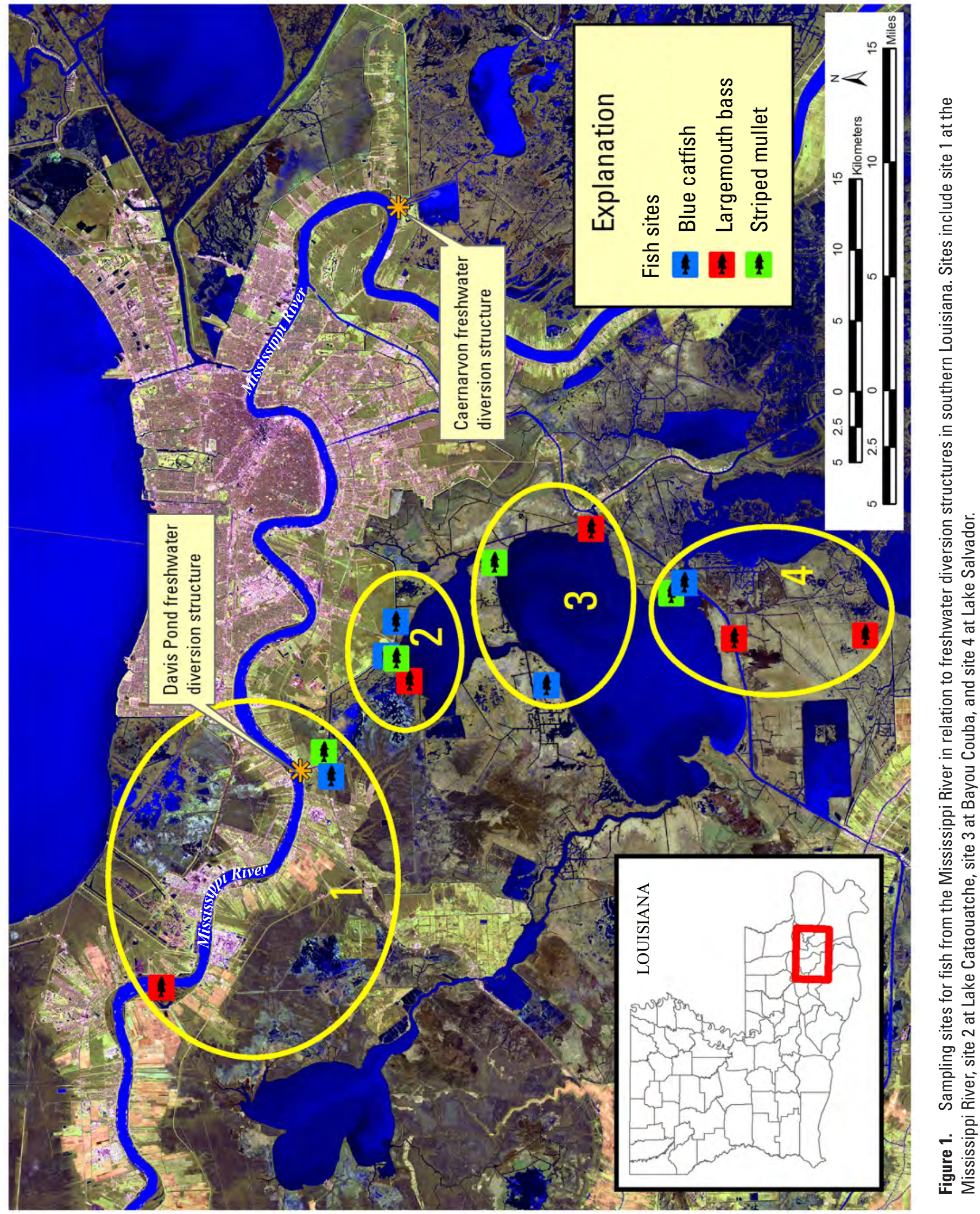




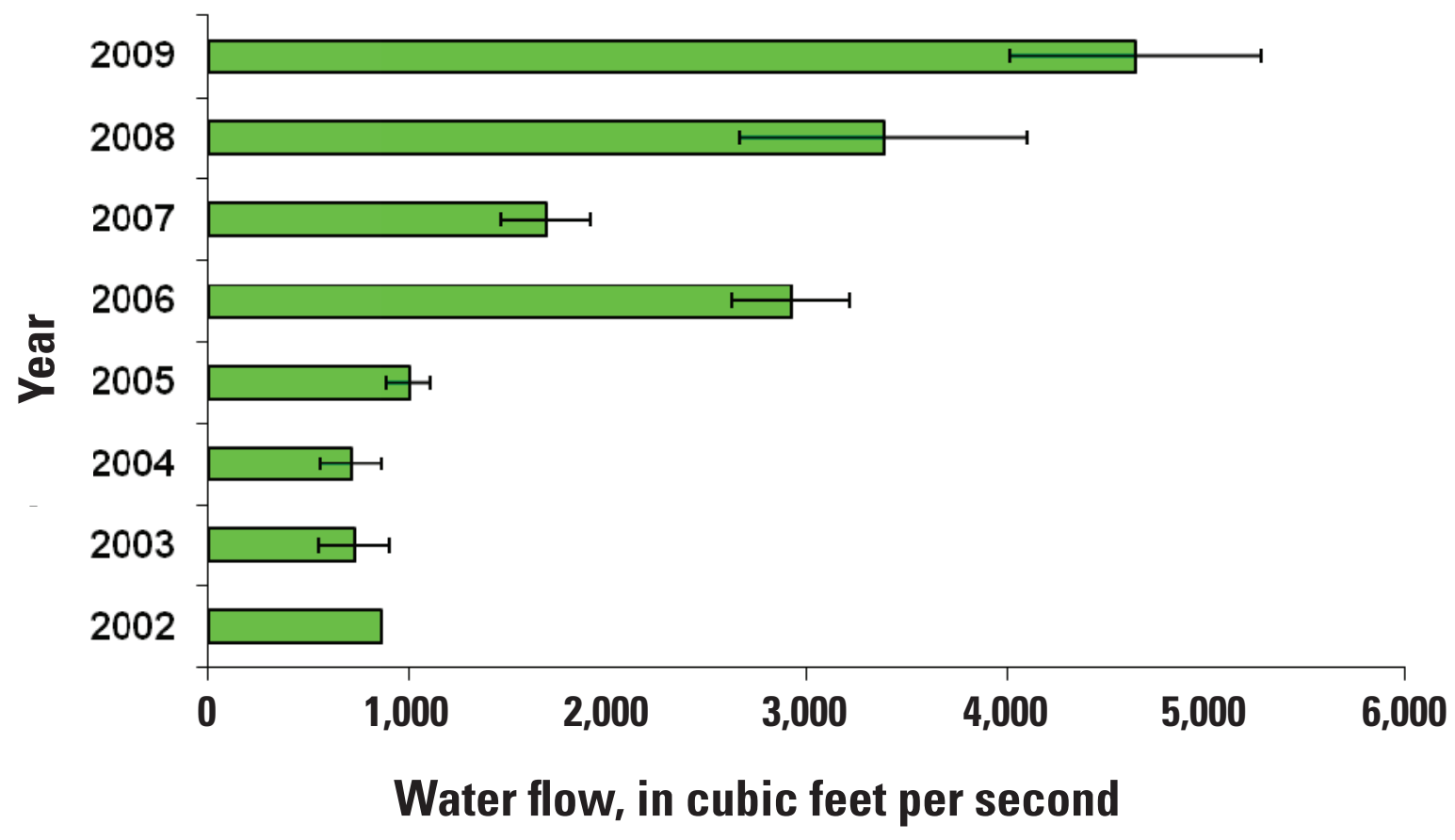

Figure 2. Annual mean water flow discharge at the Davis Pond freshwater diversion structure near Boutte, La. Data are from U.S. Geological Survey, National Water Information System, surface-water daily statistics (http://waterdata.usgs.gov/la/nwis).

diversion through the Endangered Species Act of 1973 (Public Law 93-205; 87 Stat. 884, as amended; 16 U.S.C. 1531 et seq) for endangered and threatened species, formerly including the bald eagle. Bald eagles were officially removed from the List of Endangered and Threatened Species as of August 8, 2007, but they are protected by the Bald and Golden Eagle Protection Act (54 Stat. 250, as amended, 16 U.S.C. 668a-d) and the Migratory Bird Treaty Act (40 Stat. 755, as amended; 16 U.S.C. 703-712). Because of their status, eagles and their supportive biota (including fish, bivalves, and small mammals) were the foci of these studies. Fish data are presented herein.

\section{Materials and Methods}

From December 2007 through February 2009, fish were collected, in the same way as was reported in Jenkins and others (2008), from four sites (fig. 1): Lake Salvador, Bayou Couba, Lake Cataouatche, and the Mississippi River. Thirty-six fish were harvested, 12 fish from each of three species, with 3 individuals per species per site. Species included largemouth bass (Micropterus salmoides), blue catfish (Ictalurus furcatus), and striped mullet (Mugil cephalus). Only fish within a predetermined length range were collected in order to target mature and similarly aged individuals. Sample collections were performed in accordance with protocols of the USGS Biomonitoring of Environmental Status and Trends (BEST) Program (Schmitt and others,
1995, 1999; Smith and others, 2002) and the National WaterQuality Assessment Program (Crawford and Luoma, 1993). Age was estimated by using otoliths (Beckman and others, 1990; Nieland and Wilson, 1993; Devries and Frie, 1996; Nieland and others, 2002) or fin spine increments (Ashley and Garling, 1980).

Laboratory services were performed and facilitated by TDI-Brooks International, Inc. (College Station, Tex.; see app. 1), and involved the analysis of fish whole bodies for organochlorines (OCs), polyaromatic hydrocarbons (PAHs), aliphatic hydrocarbons (AHs), trace metals, and methylmercury (largemouth bass only) (see table 1 for a list of analytes with detection limits and table 2 for registry numbers and chemical naming and abbreviations). Fish had been wrapped in food-grade heavy-duty aluminum foil (no. 2411, Alcan Foil Products, La Grange, Ga.), stored at $-20^{\circ} \mathrm{C}$, and shipped on dry ice. Standard quality-control and quality-assurance checks were performed by using duplicate samples, spiked samples, standard reference materials, and procedural blanks, and the limits of detection were defined as the Student's t for 99 percent confidence times the standard deviation of seven replicate measurements of the same lowlevel sample (Code of Federal Regulations, 2006). Sample moisture and lipid percentages were determined and factored into postdiversion data presentations. Detection limits (table 1) were equal to or below those in the SIR (Jenkins and others, 2008). Statistical analyses were performed.

Photographic images of the field sites and eagles can be found in Jenkins and others (2011). 


\section{Results}

No gross abnormalities in skeletal, skin, or internal morphology were noted in fish collected (fish data are presented in table 3, and fish weights are graphed in fig. 3). The graphic illustrations (figs. 4-27) show data associated per site locations north to south (Mississippi River, Lake Cataouatche, Bayou Couba, and Lake Salvador), and the species order per group left to right are largemouth bass, blue catfish, and striped mullet. Each file presents data from the postdiversion study above a graphic that shows both prediversion and postdiversion results. On the top graphic per element, if the chemical has a published value that represents the 85 th percentile from the National Contaminant Biomonitoring Program (NCBP) (Schmitt and Brumbaugh, 1990), a horizontal line was drawn at that number. (The 85 th percentile is an arbitrary value used to distinguish NCBP sites having elevated concentrations of the elements, which may be cause for concern.) Results are presented as parts per million (ppm), micrograms per gram $(\mu \mathrm{g} / \mathrm{g}$ ) wet weight (ww) or fresh weight (fw) for organics, and micrograms per gram dry weight (dw) for trace and major elements. This format facilitates comparison of contaminant levels in three fish species at four sampling sites before and after full functioning of the structure. Results of the analyses of the fish whole bodies for OCs, PAHs, and AHs are shown in tables 4-6.

\section{Conclusions}

Tables 7-10 show results of statistical analyses (analysis of variance) performed on data per site or grouped marsh sites versus Mississippi River fish (see app. 2); trace element ranges detected in fish from the prediversion and postdiversion studies at Caernarvon and Davis Pond, La., are presented in table 11. No detectable levels of molybdenum or beryllium were noted in any samples. Briefly, when considering the Mississippi River site in comparison with all other sites, statistically higher values of nickel, selenium (table 9), total AHs, total OCs, total DDT, DDE, and PCB values (table 7) occurred postdiversion as compared with prediversion. When reviewing values for prediversion fish, it is noteworthy that mullet were collected downstream of New Orleans (Jenkins and others, 2008), as opposed to all postdiversion fish being collected upstream of the structure intake. For postdiversion results for mercury, concentrations detected in largemouth bass were greater than those for blue catfish, which were greater than those for striped mullet $(P=0.04)$, and 53 percent of the fish collected exceeded the 85 th percentile of the NCBP (Schmitt and Brumbaugh, 1990). If more detailed results or data are needed beyond the SIR and this report, contact the authors.

\section{Acknowledgments}

We would like to thank Diane Nicks of the USGS Columbia Environmental Research Center for analysis of liver samples; Natalie G. Trahan of IAP Worldservices, Inc., at the USGS National Wetlands Research Center and Victoria Chachere Jenkins, USGS, for editorial and graphics professional assistance; Steve Hartley, USGS National Wetlands Research Center, for map production; Andre LaFosse and Tim Ruth of the Louisiana Department of Wildlife and Fisheries for field work; Juan Ramirez of TDI-Brooks International; Beth Vairin, USGS, for report production; and Alexis Parrish, Jack Larriviere, Peyton Dupre, and Eric Theall for their help in sample processing and data management.

\section{References}

Ashley, K.W., and Garling, D.L., Jr., 1980, Improved method for preparing pectoral spine sections of channel catfish for age determinations: The Progressive Fish-Culturist, v. 42 , p. $80-81$.

Beckman, D.W., Stanley, A.L., Render, J.C., and Wilson, C.A., 1990, Age and growth of black drum in Louisiana waters of the Gulf of Mexico: Transactions of the American Fisheries Society, v. 119, p. 537-544.

Code of Federal Regulations, 2006, Definition and procedure for the determination of the method detection limitRevision 1.11. Title 40, pt. 136, Guidelines establishing test procedures for the analysis of pollutants, app. B, p. 319-322.

Crawford, J.K., and Luoma, S.N., 1993, Guidelines for studies of contaminants in biological tissues for the National WaterQuality Assessment Program: U.S. Geological Survey Open-File Report 92-494, 69 p.

DeVries, D.R., and Frie, R.V., 1996, Determination of age and growth, in Murphy, B.R., and Willis, D.W., eds., Fisheries techniques, 2d ed.: Bethesda, Md., American Fisheries Society, p. 483-512.

Jenkins, J.A., Bourgeois, E.B., Jeske, C.W., 2008, Davis Pond freshwater prediversion biomonitoring study - freshwater fisheries and eagles: U.S. Geological Survey Scientific Investigations Report 2008-5067, 102 p. (Also available at http://pubs.usgs.gov/sir/2008/5067/.) 
Jenkins, J.A., Jeske, C.W., and Allain, L.K., 2011, Photographic images captured while sampling for bald eagles in marshes near the Davis Pond freshwater diversion structure in Barataria Bay, Louisiana (2009-10): U.S. Geological Survey Data Series Report 605. (Also available at http://pubs.usgs.gov/ds/605.)

Nieland, D.L., Thomas, R.G., and Wilson, C.A., 2002, Age, growth, and reproduction of spotted seatrout in Barataria Bay, Louisiana: Transactions of the American Fisheries Society, v. 131, p. 245-259.

Nieland, D.L., and Wilson, C.A., 1993, Reproductive biology and annual variation of reproductive variables of black drum in the northern Gulf of Mexico: Transactions of the American Fisheries Society, v. 122, p. 318-327.

Schmitt, C.J., Blazer, V.S., Dethloff, G.M., Tillitt, D.E., Gross, T.S., Bryant, W.L., Jr., DeWeese, L.R., Smith, S.B., Goede, R.W., Bartish, T.M., and Kubiak, T.J., 1999, Biomonitoring of Environmental Status and Trends (BEST) program - field procedures for assessing the exposure of fish to environmental contaminants: Columbia, Mo., U.S. Geological Survey Biological Resources Division Information and Technology Report USGS/ BRD-1999-0007, iv + 35 p. + appendixes, last accessed August 20, 2007, at http://www.cerc.usgs.gov/pubs/BEST/ layout-rev2.pdf.

Schmitt, C.J., and Brumbaugh, W.G., 1990, National Contaminant Biomonitoring Program - concentrations of arsenic, cadmium, copper, lead, mercury, selenium, and zinc in U.S. freshwater fish, 1976-1984: Archives of Environmental Contamination and Toxicology, v. 19, p. 731-747.
Schmitt, C.J., Tillitt, D.E., and Kubiak, T.J., 1995, Biomonitoring of Environmental Status and Trends (BEST) program - testing and implementation of selected aquatic ecosystem indicators in the Mississippi River system, 1995: National Biological Service, 10 p.

Smith, S.B., Donahue, A.P., Lipkin, R.J., Blazer, V.S., Schmitt, C.J., and Goede, R.W., 2002, Illustrated field guide for assessing external and internal anomalies in fish: U.S. Geological Survey Information and Technology Report 2002-0007, p. 1-46, last accessed March 25, 2007, at http://www.cerc.usgs.gov/pubs/center/pdfDocs/ ITR_2002_0007.pdf.

U.S. Army Engineer District, 1995, Flood control of the Mississippi River and tributaries, Mississippi Delta region, Louisiana, salinity control structures, design memorandum no. 1-Davis Pond freshwater diversion structure, supplement no. 1-biological, hydrologic, water and sediment quality monitoring program: New Orleans, La., U.S. Army Corps of Engineers, New Orleans District, 50 p.

U.S. Geological Survey, National Water Information System, 2010, Web interface, USGS water data for Louisiana: last accessed September 11, 2010, at http://waterdata.usgs. gov/la/nwis. 

